\title{
Over troeven in een moeilijke relatie
}

Citation for published version (APA):

van den Bergh-Braam, A. H. M. (1991). Over troeven in een moeilijke relatie. Maastricht University. https://doi.org/10.26481/spe.19910920ab

Document status and date:

Published: 20/09/1991

DOI:

10.26481/spe.19910920ab

Document Version:

Publisher's PDF, also known as Version of record

\section{Please check the document version of this publication:}

- A submitted manuscript is the version of the article upon submission and before peer-review. There can be important differences between the submitted version and the official published version of record.

People interested in the research are advised to contact the author for the final version of the publication, or visit the DOI to the publisher's website.

- The final author version and the galley proof are versions of the publication after peer review.

- The final published version features the final layout of the paper including the volume, issue and page numbers.

Link to publication

\footnotetext{
General rights rights.

- You may freely distribute the URL identifying the publication in the public portal. please follow below link for the End User Agreement:

www.umlib.nl/taverne-license

Take down policy

If you believe that this document breaches copyright please contact us at:

repository@maastrichtuniversity.nl

providing details and we will investigate your claim.
}

Copyright and moral rights for the publications made accessible in the public portal are retained by the authors and/or other copyright owners and it is a condition of accessing publications that users recognise and abide by the legal requirements associated with these

- Users may download and print one copy of any publication from the public portal for the purpose of private study or research.

- You may not further distribute the material or use it for any profit-making activity or commercial gain

If the publication is distributed under the terms of Article $25 \mathrm{fa}$ of the Dutch Copyright Act, indicated by the "Taverne" license above, 
wang

NQ

\section{6}

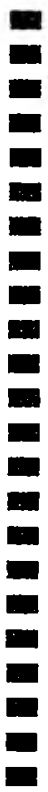

Universiteitsbibllotheek

Rijksuniversiteit Limburg

Posibus 616

6200 MD Maastricht

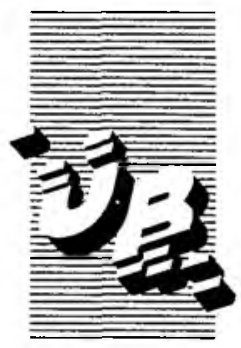

De uitleentermijn verstrijkt op:
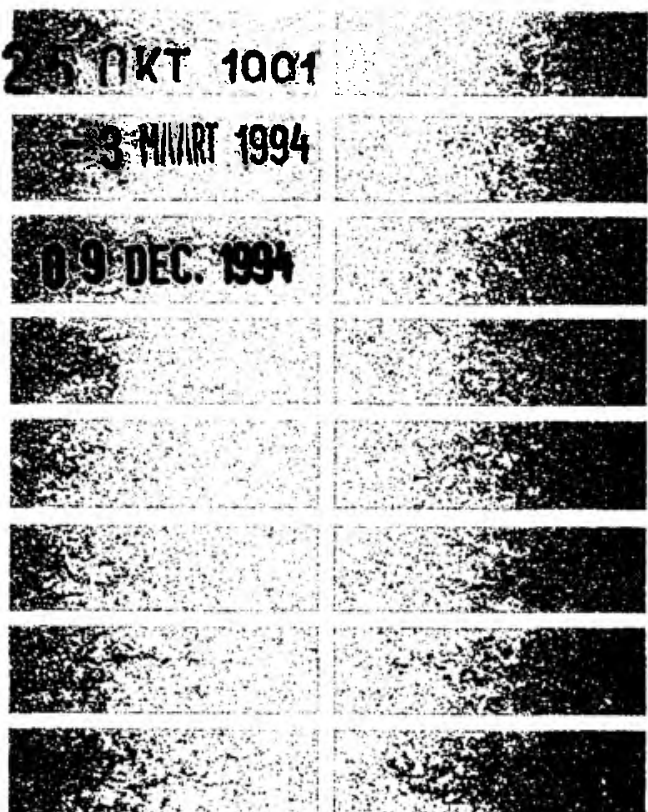

Gelieve deze publicatie tijdig te retourneren of (telefonisch) vertenging van de vitleentermijn aan te vragen. 


\section{Over troeven in een moeilijke relatie}





\section{Over troeven in een moeilijke relatie}

Rede ter gelegenheid van het afscheid van de Rijksuniversiteit Limburg gehouden door Prof.dr. A.H.M. van den Bergh-Braam

Maastricht, 20 september 1991 
$P=027107023$

Biblilotheek

R.U. Limburg

Abonn 
Mijnheer de rector magnificus,

geachte toehoorders,

Vijf jaar geleden had ik het genoegen op deze plaats te staan om voor u te spreken over "Verplegingswetenschap in Nederlands Perspectief". Het is een voorrecht om thans, bij mijn afscheidsrede, weer bij elkaar te mogen zijn en onze relaties te bevestigen die voor mijn persoonlijk en professioneel leven van zulk een grote betekenis zijn. Deze bijeenkomst biedt mij tevens de gelegenheid om een overzicht te geven van hetgeen is gerealiseerd en van mijn wensen voor de toekomst.

Allereerst wil ik mijn waardering uitspreken voor het werk van de leden van de vakgroep verplegingswetenschap te Maastricht. Het lag voor de hand dat verpleegkundig Nederland kritisch naar deze vakgroep keek, wat bij een nieuwe ontwikkeling niet verwonderlijk is. Natuurlijk liep niet alles naar wens, malar toch is er veel om trots op te zijn. In tien jaar tijd groeide het aantal studenten van tien naar meer dan zeshonderd. Onze vakgroep behoort daardoor tot de grootste afstudeerrichting binnen de faculteit der gezondheidswetenschappen. Vooral de deeltijdopleiding, een initiatief van de vakgroep, werd met enthousiasme in het veld van de gezondheidszorg ontvangen. Vele capabele studenten met een gedegen verpleegkundige achtergrond zoeken thans aan de Maastrichtse universiteit voor hun praktijkervaringen een wetenschappelijke onderbouwing. Het onderwijs aan deze groepen hooggekwalificeerde functionarissen vergt van de vakgroep bijzonder veel initiatief, flexibiliteit, creativiteit en bezinning op doelstellingen en uitgangspunten.

Ook het post hoger onderwijs (PHO) behoort tot de activiteiten van de vakgroep wier beleid zich steeds richt op het overdragen van kennis aan groepen in het veld. Om dit te realiseren werden o.m. cursussen gegeven over onderzoeksmethoden aan verpleegkundigen werkzaam op hartpatiënten-afdelingen en aan docenten in het verpleegkundig onderwijs.

Ook het organiseren van en participeren in summer-courses zijn steeds terugkerende onderwijsactiviteiten die nationaal en internationaal hoog staan aangeschreven.

Op landelijk niveau werd een samenwerking aangegaan met de Universiteiten van Utrecht en Groningen om de studie verplegingswetenschap in Nederland verder te ontwikkelen. Uitwisseling van ervaringen en diverse colleges in deze en andere onderwijsinstellingen maken Maastricht, hoewel landelijk niet centraal, tot een innoverend internationalal centrum. De vakgroep zocht en vond samenwerking met buitenlandse universiteiten, zoals met de Wayne State University te Detroit, Michigan en enkele Europese hogescholen o.a. in Edingburgh, Osnabrück en Pontypridd in Wales.

Op onderzoeksgebied ontwikkelt de vakgroep zich gunstig. Behalve dat een alantal vakgroepsleden en studenten hun promotieonderzoek met een goed resultaat heeft 
afgerond, of dit in de zeer nabije toekomst zal doen, zijn ook belangrijke subsidies voor onderzoeksprojecten verkregen. Zo mag ik wijzen op drie onderzoekslijnen, gesubsidieerd door het Ministerie van WVC. en een onderzoeksproject dat wordt gesponsord door de Hartstichting. Deze financiële ondersteuningen zijn het tastbare bewijs van een groeiend maatschappelijk vertrouwen in onze onderzoekscapaciteiten.

Ook in de maatschappelijke dienstverlening is de vakgroep actief. Leden participeren in commissies van uiteenlopende signatuur, in redacties van boeken en vaktijdschriften en adviseren in projecten betreffende nieuwe gezondheidszorgstructuren. Ook het presenteren van onderzoeksresultaten of van recent ontwikkelde visies in de verplegingswetenschappelijke wereld, zowel op nationalal alsook op internationaal niveau, maakt dat de verplegingswetenschap een substantieel element wordt, zowel in de academische wereld alsook in het veld van de gezondheidszorg. Het stimuleert talentvolle jonge mensen een carrière te kiezen binnen een zorgverlenend beroep, waaraan maatschappelijk zulk een grote behoefte bestaat.

Genoemde activiteiten weerspiegelen de evolutie in de verpleging, zowel landelijk als mondiaal. Ik wil vandalag deze ontwikkeling zien als het zoeken naar antwoorden op de steeds terugkerende vraag:" Hoe verleen ik zorg aan de patiënt die achter zijn dossier verdwijnt? Hoe overbrug ik de afstand tussen de experts en het alledalagse leven? Hoe kan ik - om met Habermas (1988) te spreken - twee polariserende domeinen met elkalar verzoenen?" Het betreft enerzijds de leefwereld met halar privé-sfeer en waarde-rationeel domein en anderzijds de systemen die berusten op doelrationeel handelen.

Doelrationeel is het handelen wanneer het zich bekommert om op de meest efficiënte en effectieve wijze concrete doeleinden te bereiken, los van morele overwegingen. Waarderationeel is het handelen wanneer het zich bekommert om fundamentele normen en waarden. Hierin worden zingevingsvragen bewust gesteld en beantwoord.

\section{Bedenkingen}

Ondanks de succesverhalen bekruipt velen een gevoel van onbehagen bij de signalen uit het veld. Wijkverpleegkundigen zeggen dat de relatieproblemen in de gezinnen ongekende proporties aannemen. Traditionele sociale bindingen verdwijnen en maken plaats voor valak ver weg gelegen, veelal onbekende instanties, die wij kunnen ervaren als anonieme machten die ons leven regelen.

Niet alleen sociale netwerken, maar ook religieuze banden bezwijken onder de doelrationele macht, die niet alleen waarderationele vragen elimineert, maar tevens een taboe legt op het spreken daarover. We komen óm in de psychosociale problematiek van patiënten en gezondheidszorgwerkers, maar weinigen vragen zich openlijk af of we in ons verlichte denken niet te veel de religie overboord hebben gegooid. Velen 
klampen zich daarom vast aan een gezondheidscultus die hen echter met vragen achterlaat.

Want de krachten van epidemieën zijn door doelrationeel handelen verbannen, maar maakten plaats voor krachten uit het universum, waarvoor de mens de waarderationele antenne verloor. Zij blijven aanwezig in het lijden, het plotselinge sterven van een geliefde en in de dreigingen van een maatschappelijke suïcide in de ouderdom. Duizenden jaren probeert de mens de terreur van dit uitzicht te ontlopen. De vorderingen op dit terrein steken schril af tegen de ingenieurssuccessen in de technologische poot van de gezondheidszorg.

Vanuit een gevoel van ontheemding zoeken velen een medische mythologie, die de zaak overneemt waar de wetenschap zwijgt. Dit verklaart waarom de gezondheidszorgdienaar niet al te onderzoeksmatig doorvraagt naar de doeltreffendheid van de steeds hoger stijgende middelen bij een steeds lager wordend rendement. De waarderationaliteit wordt langs de achterdeur binnengehaald, maar op een gevaarlijke, kostbare en verslavende wijze.

\section{Verpleging}

In deze context functioneert de verpleging.

De soms zo laatdunkend geciteerde "Middeleeuwse toestanden" liggen achter ons, maar met de afsluiting van deze periode verloor de verpleging tevens veel invloed en gezag. De bijna onaantastbare positie van de verpleging toen deze in handen was van goed georganiseerde groepen, zoals ridderorden en religieuze congregaties, bood mogelijkheden om standpunten in te nemen en, indien nodig, te verdedigen. De dienstbare verpleging van toen had een grote, van invloedrijke groeperingen afgeleide, macht. De huidige verpleging mist die macht. Ze moet zich steeds opnieuw bewijzen in een malatschappij die doelrationaliteit voorrang verleent.

Op vele manieren komt de verpleging in aanraking met de hierdoor ontstane problemen. $\mathrm{Zij}$ wordt te hulp geroepen bij ouderen die in hun vereenzaming noch soelaas vinden binnen hun sociale netwerken, noch binnen de voor hen opgerichte instituten. Dit geldt ook voor psychiatrische patiënten. Berucht is de draaideur-problematiek van psychiatrische klinieken, waar ontslagen patiënten weer even snel binnenkomen als zij naar buiten zijn verwezen. $\mathrm{Zij}$ zoeken de beschutting van het instituut omdat de maatschappij, juist als een negentiende-eeuws weeshuis "je niet laat sterven, maar je ook geen zorg en aandacht schenkt".

Patiëntenverenigingen zeggen dat de kilheid van de maatschappij in onze gezondheidszorginstellingen doordringt. Verpleegkundigen menen dat de gemeenschap zèlf hiervoor verantwoordelijk is. Volgens hen ligt het centrale dilemma van de huidige verpleging in het feit dat het een beroep is met een opdracht tot zorg, in een malatschappij die aan zorg een geringe walarde hecht. Het is het probleem van het geveclit 
tussen doelrationaliteit en waarderationaliteit, waarbij laatstgenoemde in de moderne gezondheidszorg het pleit dreigt te verliezen.

Vele verpleegkundigen trachten tegengas te geven door hun werkzaamheden dusdanig te organiseren dat zij waarderationele aspecten in de doelrationele gezondheidszorg kunnen integreren, zoals b.v. bij patiënt-gericht verplegen. $\mathrm{Zij}$ bezielen daardoor de hulpverlening en vormen een opvallend element in de kwijnende zorgcultuur. Vele verpleegkundigen geven de ervaringen die zij daarbij opdoen dóór aan collega's in het veld. Bij "thuiskomst" treft hen dan soms het lot van Gulliver, die na vele omzwervingen ontwaakte, vastgenageld aan de grond, door de listen van honderden lilliputters.

Sommige omringende functionarissen blijken nl. patiënt-gericht verplegen te ervaren als een aanslag op hun autonomie. Niet zelden nemen zij tegenmaatregelen die de voortgang van de projecten verhinderen.

Inmiddels blijkt dat patiënten de problematische relatie doelrationaliteit versus waarderationaliteit op eigen wijze benaderen. Wij zijn getuigen van ontwikkelingen die, naar mijn mening, uniek zijn in de geschiedenis van de gezondheidszorg. Het gaat om twee tegenstrijdige stromingen. De eerste betreft de behandeling. Patiënten zoeken voor hun genezing de meest geavanceerde technologische hulp in de top van de gezondheidszorg, binnen de paleizen van de doelrationaliteit. Het "hogerop-syndroom" is berucht in de huisartsenpraktijk. De tweede, hieraan tegengestelde beweging geldt de verzorging, walarvoor patiënten juist in het dal van hun directe leefmilieu om aansluiting vragen. De controverse tussen systeem en leefwereld (Habermas 1988) komt hierin tot uitdrukking. Begrijp ik het goed en zeggen patiënten massaal:"De behandeling is oké, maar de verzorging ondermaats?". Deze boodschap contrasteert met de in het begin van deze oratie gepresenteerde evaluatie van de verpleging.

Waarin falen wij?

Hebben wij in onze ontwikkeling de essentie van de verpleging gemist of zijn onze problemen te herleiden tot variaties op oude thema's die zich in de loop der geschiedenis steeds onder andere gedaanten manifesteren?

Ik geloof dat wij nog steeds de kern van de verpleging trachten te raken, maar dat wij bij onze pogingen soms de juiste troeven missen.

\section{Het kaartspel}

Bij het bestuderen van de historie van de gezondheidszorg, zie ik de verpleging als een kaartspel met een wisselende combinatie van steeds terugkerende elementen die soms uiterlijk, maar nooit wezenlijk verschillen. De kalarten van de verpleging zijn, in termen van het verplegingswetenschappelijke model: 
- ziekte/gezondheid

- individu

- verpleging

- omgeving.

Combinaties van deze vier concepten in nieuwe, steeds wisselende formaties, bepalen het verpleegkundig handelen.

Maar niet alleen een wisselende samenstelling, doch ook een verandering van focus, d.w.z. verandering van troeven, geeft in mijn opvatting de verpleging haar tijdgebonden dimensie. Dit verwoordde ik reeds (Van den Bergh-Braam 1986) in mijn inaugurele rede door te stellen:

"De focus van de verpleging is niet onveranderlijk. Verpleging heeft een tijds- en urgentiedimensie. Dit is één van de redenen waarom er zoveel uiteenlopende definities van verpleging bestaan."

\section{Veranderende troeven}

In de agrarisch-ambachtelijke samenleving was de zorg voor de omgeving noodzakelijk om te kunnen overleven. Behuizing, voeding en beschutting stond daardoor centraal in het dagelijks leven.

In de industriële samenleving komt de nadruk te liggen op de techniek. Ook verpleegkundige vaardigheden en verpleegkundige technieken krijgen prioriteit.

In de postindustriële samenleving richt de aandacht zich primair op communicatie. Het is echter een objectieve communicatie, ontdaan van de subjectieve dimensie. Het röntgenapparaat communiceert met de patiënt, of liever gezegd met een onderdeel en een facet van de patiënt. De laboratorium-test is eveneens een objectief, communicatief verhaal tussen een chemische substantie in de reageerbuis en het weefsel van de patiënt. Wat wij missen in deze, vaak tot sprookjesachtige hoogten geperfectioneerde technologische en chemische samenspraak, zijn de surplus-factoren (Habermas 1988 zou zeggen "De niet geblokkeerde communicatie") die het kille, afstandelijke en onmenselijke weer humaniseren.

Maar niet alleen de surplus-factoren rond de technologische en chemische samenspraak bepalen de menselijkheid van de behandeling en verzorging, maar ook die tussen de organisatie en de daarin werkende mensen en de maatschappij en haar burgers. Deze drie niveaus van surplusfactoren, te weten die tussen de technologie en patiënten, de organisatie en haar leden, de maatschappij en haar burgers, wil ik graag benoemen met de term "omgeving". Het is een kaart uit het verplegingswetenschappelijke kaartspel, die ik voor de toekomst graag als troefkaart wil inzetten. 


\section{Omgeving}

Met de visie dat in de problematiek van de gezondheidszorg "de omgeving" een cruciale schakel vormt, staat niemand minder dan Hippocrates (ca. 460 v.C.-377? v.C.) aan mijn zijde. Kenmerkend voor zijn instelling is om niet slechts de ziekte te beschouwen, maar de patiënt in een zo breed mogelijke omgeving. Hippocrates zegt:(Powles 1973)

"De arts die zijn beroep in ere houdt, dient op de seizoenen van het jaar te letten en op de ziekten waartoe deze leiden; hij dient zorgvuldig de ligging van de steden en van de omringende streek in het oog te houden, of deze latg of hoog zijn, warm of koud, nat of droog; hij dient bovendien de voedings- en leefregels van de bewoners op te tekenen en uiteraard ook alle mogelijke oorzaken die tot wanorde in de economie der dieren zou kunnen leiden."

In de loop der eeuwen ging de wetenschap andere prioriteiten stellen, waarbij de ecologische beginselen uit het oog werden verloren. Maar het tij gatat keren. Er ontstaat een nieuwe bereidheid om een diagnose over "slechte leefgewoonten" te maken en een nieuwe behoefte aan harmonie met de natuur. Discussies over dit belangrijke onderwerp staan nog pas aan het begin, maar zullen in de komende jaren belangrijke gespreksonderwerpen worden.

Hoe staat de verpleging tegenover deze ontwikkeling?

\section{Verpleging en omgeving}

Met veel respect wil ik de activiteiten van de verpleging in dezen gedenken. Zojuist wees $i k$ reeds op hun inspanningen t.a.v. patiënt-gericht verplegen.

Toch kan ik mij niet aan de indruk onttrekken dat de meeste bemoeienissen zich richten op het direct patiënt-gecentreerde niveau, het z.g. "micro-niveau". Verpleegkundigen proberen daar eilandjes van warmte te zijn, maar botsen op tegen belêmmeringen uit het meso- en macro-niveau, waarvoor velen geen strategieën ontwikkelen.

Wat mij bij de ontwikkeling van de verplegingswetenschap interesseert is niet uitsluitend de laatste fase van het kaartspel, maar ook de activiteiten op meso- en macro-niveau. Wie schudt en deelt de katarten? Wordt daarbij eerlijk gespeeld? Wie bepaalt de troef? Is het stok kaarten intact? Wat gebeurt er op het macro-niveau waar de politieke goochelaar zijn revenuen haalt? 


\section{Het spel}

Van Londen (1990), voorzitter van de Nationale Raad voor de Volksgezondheid, zegt geen enkele instantie te kunnen aanwijzen die het spel definitief beïnvloedt. Ziekenhuisdirecties daarentegen menen dat het de politiek is die de kaarten schudt en dat medici met virtuositeit de troeven uitspelen. Medici ontkennen dat en zeggen dat de politiek en ziekenhuisdirecties onder één hoedje spelen. En verpleegkundigen vertellen dat het schudden en delen niet eerlijk verloopt.

Nu mag men nooit verwachten dat mensen hun samenleving in roerende eensgezindheid zullen opbouwen, maar de huidige gebeurtenissen in de gezondheidszorg geven wel een extreem staaltje van blind, ongepland handelen, waarvan noch de inzet, noch de uitkomst voorspelbaar is. Van Londen (1991) zegt dan ook:"Ik ben in voortdurende staat van alarm".

Patiënten uiten soortgelijke klachten en zeggen dat hun wezenlijke hulpvraag in veel gevallen door de gezondheidszorg niet wordt beantwoord. Het is onjuist om uitsluitend de geneeskunde hiervoor verantwoordelijk te stellen. Het verwijt treft evenzeer de verpleegkunde.

Onze hulpverlening aan eenzame bejaarden mondt zelden uit in malatschappelijke acties tot herstel van sociale netwerken. Voor de gigantische relatieproblemen walarmede wijkverpleegkundigen worden geconfronteerd bestaat een maltschappelijk georiënteerde theorie die mogelijk oplossingen kan brengen. Maar wie kent of hanteert deze visie, afkomstig van Simmel? Hij wijst op het gemak waarmede in vroegere tijden partners hun emotionele verwachtingen konden realiseren in gilden, buurt, kerk en ontspanningsverenigingen. Thans vallen deze ondersteunende structuren weg en kunnen levensgezellen hun emoties slechts binnen hun één-tot-één-verhouding realiseren. Deze brug blijkt vaak te zwak voor deze zware druk. De adviezen van wijze ouders aan de bruid: "Blijf zorgen voor een goede vriendinnen-club" (voor de bruidegom meestal overbodig) heeft meer wetenschappelijke diepgang dan men op het eerste gezicht vermoedt.

Vervolgens: de begeleiding van patiënten uit de high-tech-instituten nalar het eigen leefmilieu is zelden bevredigend. De hartpatiënt, van zijn bewakende technische monitoren bevrijdt, krijgt thuis te maken met menselijke monitoren die niet op hun taak zijn voorbereid. De conflicten die hieruit ontstaan veroorzaken vaak veel leed.

En tenslotte: hoe is onze visie op de thuiszorg van chronisch zieken en bejaarden binnen de kwetsbare structuur van het nucleaire gezin? Wie zal de verzorgers verzorgen? Het is een maatschappelijk probleem dat verpleegkundigen helaas te valak op individueel niveau benaderen, terwijl in feite structurele oplossingen geëigend zijn, zoals op systematische wijze en gezette tijden het uit huis halen van patiënten, waardoor verzorgers zich kunnen ontspannen. 
Andersoortige structurele oplossingen voor de toenemende spanningen in de gezondheidszorg tussen doelrationaliteit en walarderationaliteit, met de daaraan inherente onbeheersbaarheid van kosten, zijn het oprichten van privé-klinieken en het invoeren van marktbeginselen. Het ligt niet in mijn bedoeling om in een palir woorden deze stroming te evalueren. Wel wil ik wijzen op een essenticel kenmerk van de zakenwereld dat ook in de gezondheidszorg zo dringend noodzakelijk is, n.l. een constante radar voor omgevingssignalen. In onze ziekenhuizen, zoals in alle non-profit organisaties, bestaat de verleiding zich in slaap te sussen met "het nobele motief" en dit als substituut te hanteren voor het uiteindelijke resultaat. Het is juist deze valkuil die de succesvolle zakenwereld vermijdt door constant duidelijk te omschrijven welke veranderingen buiten de organisatie het resultalt beïnvloeden en daarop het beleid af te stemmen.

Deze benadering contrasteert met de soms puur naar zichzelf verwijzende interne discussies van verpleegkundigen en verplegingswetenschappers. Begrijp me goed, ik ben blij en trots op de ontwikkelingen in de verpleging, zoals het classificeren van verpleegkundige diagnose-categorieën en het beheer van eigen werkziamheden, maar zij mogen niet het luisteren naar de omgeving verhinderen. Het luisteren nalar de wensen van het publiek betekent tevens de gegevens uit het meso- en macroniveau bestuderen. Dit vergt een enorme creatieve ongang met het veld. Wij leven in een maatschappij die steeds méér trekjes van een kastemaatschappij gaat vertonen; een samenleving met besloten groepen waarin niet de materiële schaarste het grootste probleem is maar gebrek ain relaties, sociale netwerken, contacten en vriendschappen. De onderste kaste bestaat uit mensen die om welke reden ook zich in zulke gebrekkige sociale structuren bevinden dat ze zelfs geen dak boven hun hoofd hebben: nieuwkomers, weggelopen jongeren, contactgestoorden, psychisch labielen, verslaafden. Hoe komt het dat de verpleging zich zo marginal onder die groepen begeeft?

Als er geen krachtige, goed geïnformeerde verplegingswetenschap ontstalat, één die zich uitdrukkelijk profileert op zowel interne en externe zaken, alsook op psychosociale en politiekeconomische aspecten van de omgeving, dan blijft er voor de verpleging weinig anders over dan zo nu en dan de vinger in de lucht te steken om te voelen waar de wind vandaan komt. De groeiende conflicten tussen doelrationaliteit en waarderationaliteit zullen de niet geïnformeerde verpleging overrompelen en daarmede de kern van de hulpverlening aantasten. Men achterhaalt de noden van patiënten niet door het meso- en macro-niveau de rug toe te keren, maar door zich erin te storten, in de overtuiging dat kennis omtrent de brede omgeving de visie op het micro-niveau ten goede komt.

Ik heb het gevoel dat de verpleging zich de invloed van de omgeving op het verpleegkundig handelen onvoldoende realiseert. Als ik in Nederland pleit voor meer 
aandacht voor de omgeving, krijg ik vaak ten antwoord:"Waarom, dat hebben medici toch ook niet?".

Wat mij vooral beklemt is het feit dat door de blinde vlek voor de omgeving van de patiënt niet alleen soms de juiste begeleiding ontbreekt, maar ook soms onjuiste vooronderstellingen wordt gemaakt, niet zelden onder het mom van wetenschappelijkheid. Wij hebben veel te danken aan de Amerikaanse verplegingswetenschap, maar getuigt het niet van wijsheid als wij ons afvragen of de Amerikaanse verplegingswetenschappelijke theorieën niet op een speciale maatschappelijke omgeving zijn geënt, die niet vanzelfsprekend gelijkt op de Nederlandse samenleving? Met deze overwegingen in gedachte kunnen wij misschien meer en beter begrip opbrengen voor stemmen uit het veld die klagen over het Amerikanisme in de Nederlandse verplegingswetenschappelijke ontwikkelingen.

\section{Positief}

De visie, als zou het bestuderen van de omgeving dienen te worden gereserveerd voor een verpleegkundige sociologie, analoog aan de medische sociologie, lijkt mij onjuist. Wetenschap ontwikkelt zich niet in platonische isolatie, malar in wisselwerking met de maatschappij. Heeft het verwaarlozen van dit principe de gezondheidszorg niet reeds parten gespeeld? Zou de geneeskunde zich niet beter hebben ontwikkeld als zij de wijsheid van Hippocrates was blijven eerbiedigen?

Trouwens, het zijn onze eigen verpleegkundige voortrekkers die wijzen op het belang van de omgeving voor het verpleegkundig handelen.

Florence Nightingale werd een verpleegkundige hervormer en legde de basis voor verplegingswetenschappelijke benaderingen toen zij de wantoestanden op microniveau ging herleiden tot fouten op meso- en macro-niveau.

Virginia Henderson (1986) zegt dat de meest succesvolle opleiding tot verpleegkundige zich altijd dient te richten op het overdragen van een breed begrip voor het menselijke en de wereld waarin zij leven.

Madeleine Leininger (1978) zegt:" What counts as caring is highly context-dependent".

En Rebecca Bergman (1990) wijst in haar toespraak ter gelegenheid van het vijftienjarig bestaan van de verplegingswetenschap aan de universiteit te Tel Aviv op de noodzaak om in brede verbanden te denken.

De verplegingswetenschap behoeft deze omgevingsaspecten niet tersluiks binnen te smokkelen. Zij kunnen worden uitgewerkt op basis van internationaal algemeen geaccepteerde kernconcepten. Het zijn, om in termen van deze voordracht te blijven, erkende kaarten in het verplegingswetenschappelijke kaartspel. Hoe zal dit spel verlopen? 


\section{Veranderende omgeving}

Wat de veranderingen in de omgeving betreft: wij zullen moeten accepteren dat in de toekomst concurrentie een grote rol gaat spelen. Ziektekostenverzekeraars zullen met globale contracten de grenzen van de zorg bepalen en ziekenhuizen en verpleging tot een marktgericht perspectief dwingen. En marktbeginselen kweken killere rekenmeesters dan professionals ooit zijn geweest. Dit marktmechanisme is bedoeld om de kostenexplosie te drukken. Ik vraag me af of dit met de huidige basisverzekering en het stelsel van normuitkeringen per verzekerde kan worden bereikt. Bezuinigingen beginnen met het opstellen van een duidelijk beeld van de kosten, uitgesplitst naar het produkt. Maar een reële calculatie van het feitelijke aandeel van de verpleging in de ziekenhuisrekening van de patiënt is tot nu toe steeds "natte-vinger-werk" geweest. Onze rekenmeesters zakken door de bodem van een verouderde ziekenhuistraditie. Het is daarom de vraiag of hun calculaties wel zo zakelijk kunnen zijn als zij zich wensen. En de gezondheidszorg heeft veel te duchten van een quasi-zakelijk beleid.

Wij staan voor een gigantisch probleem van een te weinig geinformeerde overheid en logge, complexe gezondheidszorgstructuren. In de conflicten die zullen ontstaan moeten verpleegkundigen hun beste onderhandelingsvaardigheden alanwenden om niet beklemd te raken tussen de komende matregelen. Mede dalarom dienen wij ons te verzekeren van de steun van de politiek en het publiek. Om dit te realiseren dienen wij sterke en zichtbare leiders te stimuleren. Mensen die voor de verpleging spreken, zowel binnen alsook buiten de professie.

\section{Opleiding}

Zulk een veranderende omgeving vraagt tevens om een goede verankering in de opleiding van adequate kennis en vaardigheden. Het onderstreept de noodzaak van een brede, algemene bisisopleiding, gevolgd door een specifiek gerichte bovenbouw. Want welke strategieën wij ook voor de ontwikkeling van de verpleging willen volgen, de enige manier om als professionals in de gezondheidszorg te kunnen overleven is gelegen in hun effeclieve, efficiënte en zorginhoudelijke competentie. Patiëntenzorg zal niet alleen met grote precisie worden gepland, maar ook worden bevorderd door de mogelijkheden van hulpverleners om vlug per computer het hele netwerk van zorgprotocollen te kunnen raadplegen, teneinde de nieuwste technieken te kunnen toepassen.

Een zeer stipte wetenschappelijke onderbouwing van het verpleegkundig handelen zal voorrang krijgen. Daarom dient de verplegingswetenschap door te gaan met het ontwikkelen en evalueren van conceptuele modellen, die constant worden onderworpen aan de kracht van onderzoek. Wij moeten deze kennis consistent in de verpleegkundige praktijk toepassen. 
Maar wat de student van de universiteit dient mee te krijgen is niet alleen loutere kennis, maar ook datgene wat richting geeft aan het gebruik daarvan. Pascal (1962) heeft geschreven:"Wij kennen de waarheid niet alleen met ons verstand, maar ook met ons hart." De verpleegkundige praktijk vereist niet alleen wetenschappelijke kennis en technische vaardigheden, maar ook het accepteren, herkennen en beleven van menselijke waarden. Slechts een combinatie van kennis en begrip leidt tot een wijsheid die de juiste benadering van onze cliënten garandeert, zonder onze eigen normen en waarden aan hen op te dringen.

\section{Veranderingen in eerste- en tweedelijns gezondheidszorg}

Waarschijnlijk zullen de grootste veranderingen zich voltrekken in de systemen van de gezondheidszorg. Het succesvolle ziekenhuis van de toekomst zal een totaal ander concept hebben dan het huidige. Het zal tot in de huizen reiken. Het zal beantwoorden aan het begrip "Ziekenhuis zonder muren". Dit is een logisch gevolg van veranderende maatschappelijke opvattingen. Want is het ziekenhuis in de huidige vorm een produkt van de denkwijze in het industriële tijdperk en het modernisme, dan is het ziekenhuis zonder muren het produkt van opvattingen in de postindustriële periode en het postmodernisme. Het zal veelsoortige diensten verlenen aan patiënten in de thuissituatie, die normaliter in het ziekenhuis zouden moeten worden opgenomen. $\mathrm{Zij}$ worden thuis behandeld en verzorgd tot aan het tijdstip dat gespecialiseerde voorzieningen alsmede intensieve zorg noodzakelijk zijn. In dit verband is het onvermijdelijk dat verpleegkundigen zich oriënteren op een vloeiende overgang tussen de ziekenhuishulp en eerstelijns-hulp en vice versa.

Dames en heren, dierbare studenten,

De onvolmalaktheden en onrechtvalardigheden in de gezondheidszorg, resulterend in een te grote afhankelijkheid van patiënten en onvoldoende zorgvuldigheid in hun benadering, worden in het algemeen toegeschreven aan de gevestigde belangen van professionals en managers.

Wij dienen echter achter deze factoren te kijken, naar de vooronderstellingen en overtuigingen die daaraan ten grondslag liggen. Ik meen dat de dominantie van professionals en bureaucratische organisaties wordt gedragen door de overtuiging dat de sociale problemen van onze maatschappij het best kunnen worden opgelost door de wetenschap in de vorm van professionele deskundigheid en wetenschappelijk management. Dit naïef geloof in de wetenschap bestendigt een systeem dat zowel professionals alsook patiënten benadeelt.

Als wij ons in deze malalstroom laten meevoeren, kan de opkomst van de verplegingswetenschap dit probleem slechts versterken. Maar pogingen om de afhankelijkheid van patiënten t.o.v. zorgverleners te verminderen, zullen onherroepelijk falen als de sociale omstandigheden en de overtuigingen die deze afhankelijkheid legiti- 
meren, worden genegeerd of onjuist ingeschat. Wéér wijs ik dus op de omgeving als een cruciale factor bij een hervormingsbeleid.

U stalat aldus voor een dilemma: Als u de onvolkomenheden in organisaties en wetenschap accepteert, ondergraaft dit uw bereidheid om de disfunctionaliteit ervan te bestrijden. Maar als u daarentegen de onvolkomenheden in de organisaties en wetenschap wél ter discussie stelt, dan zullen uw hervormingspogingen slechts succes hebben als $u$ de sociale condities en overtuigingen walirop deze onvolkomenheden berusten, wilt onderkennen.

\section{Hoe verder?}

\section{Hoe kunt u verder?}

Het zal u warschijnlijk niet verbazen dat voor mij de toegangspoort tot veranderingen in de gezondheidszorg ligt in het modificeren van de sociale condities en het expliciet aan de orde stellen van de vooronderstellingen en overtuigingen die alan de huidige professionele macht ten grondslag liggen.

Wat de sociale condities betreft: deze zijn extreem weerbarstig en moeilijk te beïnvloeden, daar zij zijn ingebed in de basisstructuren van de maltschappij. Ik geloof echter dat een essentieel wijzigingsproces in de sociale omstandigheden kan intreden als wij erin slagen netwerken valn wederzijdse hulp in de maatschappij te scheppen. Wat de bewustwording van valak onbewuste overtuigingen betreft: de verplegingswetenschapper zal nalar het publiek open dienen te zijn over de beperkingen valn de professionele deskundigheid t.o.v. sociale problemen, zoals dair zijn:

- de overschatting van de wetenschappelijkheid van professionele beslissingen;

- de eenzijdigheid in de probleemdefinities van professionals, in samenhang met de beperktheden van individuele deskundigheden:

- de niet reële veronderstelling dat alle problemen oplosbaar zijn;

- het negeren van niet-rationele factoren in sociale problemen.

Dierbare studenten, ik zou deze summiere handleiding bij een uiterst moeilijke materie niet aan u durven slijten, als niet in mijn achterhoofd een breder uitgewerkt programma had postgevat. Het is de Primary Health Care (PHC) benadering, een wereldwijd plan, ondersteund door de Wereldgezondheidsorganisatie (WHO). Velen noemen de WHO tevens als initiatiefnemer daarvan. Ik heb dalar mijn bedenkingen bij. Reeds een jaar voordat de WHO deze plannen lanceerde (tijdens de Almal Ata conferentie in 1978) was het een verpleegkundig hoogleraar: Professor Annie Altschul (Smith 1978) die sprak over de noodzaak van PHC. Malar de geschiedenis wordt wel vaker herschreven.

Primary Health Care is niet alleen een zorg die zich richt op facetten als toegankelijkheid, betalalbaalarheid, herkenbalarheid, gemeenschappelijkheid en aanpasbaar- 
heid. $\mathrm{Zij}$ richt zich bovenal op een zorgverlening in de eigen OMGEVING. En daarmede is de cirkel van deze voordracht rond.

Ik begon met mijn bezorgdheid uit te spreken over de signalen uit het veld, die de succesverhalen van de verpleging nuanceren. Ik stelde vervolgens dat het systeem en de leefwereld steeds verder uit elkaar drijven en pleitte voor een betere integratie, waarbij meer aandacht voor de omgeving een cruciale rol kan spelen. De Wereldgezondheidsorganisatie maakt met haar propaganda voor Primary Health Care de omgeving tot een troefkaart in haar pogingen de gezondheidszorg en de cliënt opnieuw bij elkaar te brengen en daarmede ook doelrationaliteit en waarderationaliteit met elkaar te vervlechten.

Aan het begin zag ik tevens - niet zonder trots - Hippocrates aan mijn zijde bij mijn pleidooi voor méér aandacht voor de omgeving. Thans, aan het einde van mijn oratie, steun ik op Habermas als gids. Hij wijst op veelbelovende ontwikkelingen binnen de maatschappij waar zich groepen formeren die zich tussen "het systeem" en "de leefwereld" begeven om een horizontaal samenspel te bevorderen. Zij breken buiten de hen toegewezen kaders en voeren discussies en acties o.a. rond de antipsychiatrie, het welzijnswerk, de milieu-voorzieningen, de nucleaire bewapening, de vrouwenemancipatie en de ontmedicalisering. In mijn visie behoren in deze gelederen ook thuis de verpleegkundige acties ter bevordering van Primary Health Care.

In zijn filosofie over de maatschappelijke invloed op het individu stelt Habermas (1990) o.a.:"Niemand is in z'n eentje verantwoordelijk voor zijn zelfmoord" Deze uitspraak zou ik willen toepassen op de gezondheidszorg die ik niet alléén verantwoordelijk wil stellen voor haar problemen. Wij allen hebben deel aan haar lot.

Mijnheer de rector, dames en heren,

Ik ben dankbaar voor wat we bereikt hebben, maar zal mij blijven realiseren dat er geen einde zal komen aan onze gezamenlijke inspanningen, omdat hetgeen vóór ons ligt een dynamische toekomst is. Ik neem afscheid met het volste vertrouwen in de toekomstmogelijkheden van onze talrijke begaafde en enthousiaste studenten. Hopelijk zult u, studenten, zich blijven realiseren dat een ontwikkeling niet alleen binnen de toppen plaatsvindt, maar dat daarbij voeding en medewerking uit het veld nodig is. Dáár moet de verpleging wedijveren met vele andere beroepsgroepen om de harten en zielen van jonge mensen die voor een beroepskeuze staan. Het is aan jullie om de toekomst zo te beïnvloeden dat vele getalenteerde jongeren onze richting zullen kiezen.

Wij maken moeilijke tijden door in de huidige chaotische herstructurering van de gezondheidszorg. Maar optimisme en vertrouwen blijft noodzakelijk. Het Chinese spreekwoord zegt:"Als ik een groene twijg in mijn hart bewaar, zal de zangvogel zeker komen". 
Mijn vertrouwen geldt ook de vakgroep verplegingswetenschap, die na een stormachtige take-off periode thans in een wat rustiger klimatit onderwijs en onderzoek kan behartigen. Jullie bijzondere prestaties onder de druk vill massatil toestromende studenten verdienen bijzondere vermelding.

Mijn vertrouwen geldt bovenal mijn collega professor dr. Huda Huijer. Beste Huda, een dynamische toekomst ligt voor je, walarin je, te zamen met de vakgroep belangrijke besluiten moet nemen. Ik heb het volste vertrouwen in de kwaliteiten van je beslissingen en de gevolgen daarvan voor de verplegingswetenschap in Nederland. Hartelijke dank voor je inzet.

Mijn beste wensen gaan tevens uit naar professor dr. Hans Philipsen die in de moeilijke beginperiode het roer niet losliet en bleef stain waar hij nodig was. Beste Hans, als verpleegkundige zeg ik:"Je bent niet één van ons, mair een omgevingsfactor". Als ik ooit een betere illustratie voor de noodzalak van omgevingsfactoren in de verplegingswetenschappelijke uitgroei kan alutonen, is het wel hier. Vakgroepleden hebben geen beter bewijs voor de juistheid van mijn centrale stelling nodig, die luidt:"Malak de omgevingskaart troef in het verzoenen van tegenstellingen:. Heel ondeugend voeg ik hieraan toe dat je ook meerdere trucjes in het kalartspel toepaste. Soms kreeg ik de indruk dat je een kaart onder tafel liet verdwijnen of bij je buurman afkeek. Jij liet je meestal niet in de kalarten kijken, malr toch hebben wij wel een indruk van je strategieën, die mede de grote uitgroei van de verplegingswetenschap in Nederland bepaialden.

Hartelijk dank voor je inzet.

En wat mijzelf betreft: ook ik stel mijn vertrouwen op de omgeving. Het simen verder galan met mijn echtgenoot biedt een aantrekkelijk perspectief, dat versterkt wordt door onze goede band met de kinderen en a.s. schoondochter en schoonzoon. Het is niet moeilijk om door dit én het prachtige natuurschoon dat ons omringt, de groene twijg in het hart te bewaren. Uitkijkend over het natuurreservalat "De Ooy" zal ik de zangvogel zeker horen.

Ik dank u voor uw belangstelling.

Maastricht 20 september 1991

A.H.M. van den Bergh-Braam. 


\section{Geraadpleegde literatuur}

Bergh-Braam, A.H.M. van den. Verplegingswetenschap in Nederlands perspectief. Leiden: Spruyt, Van Mantgem en De Does 1986.

Bergman, R. Thoughts on the future of nursing. Journal of advanced nursing 1990 , $15,865-866$.

Habermas, J. Erkenntnis und Interesse. Frankfurt am Main: Suhrkamp,1988.

Habermas, J. De Wiedervereinigung moet de bewuste akt van een politieke wil zijn. De Groene Amsterdammer 11 April 1990.

Henderson, V. Some observations on health care by health services or health industries. Journal of advanced nursing 1986, 11, 1-2.

Leininger, M.Transcultural nursing - concepts, theories and practice.

New York: Wiley and Sons 1978.

Londen, J. van. Over de rolverdeling bij het beleid. Medisch Contact 1990, $36,45,1054$.

Londen, J. van. Ik ben in voortdurende staat van alarm. NRC Handelsblad 30 Maart 1991, 3 .

Pascal, B. Pensées. Paris: Guitton 1962, 236.

Powles, J. Naar een theorie over geneeskunde van de industriële mens. Hulpverlenen en veranderen 1973, 4, 43, 1-21.

Smith, J.P. Professional nursing through the curriculum. Journal of advanced nursing $1978,3,331-332$. 